\title{
The Urgence and Reflection of Multicultural Islamic Education, Democracy and Human Rights in Indonesia
}

\author{
Agus Yosep Abduloh \\ STAI Miftahul Ulum Tasikmalaya, West Java, Indonesia \\ Corresponding Author: e-mail: agusyosepabd01@gmail.com \\ Uus Ruswandi \\ UIN Sunan Gunung Djati Bandung, West Java, Indonesia \\ uusruswandi@uinsgd.ac.id \\ Mohamad Erihadiana \\ UIN Sunan Gunung Djati Bandung, West Java, Indonesia \\ erihadiana@uinsgd.ac.id \\ Naeli Mutmainah \\ RA Nurul Huda Kota Banjar, West Java, Indonesia \\ naelimutmainah.ney@gmail.com

\section{Hisam Ahyani} \\ STAI Miftahul Huda Al Azhar Banjar, West Java, Indonesia \\ hisamahyani@gmail.com
}

\begin{abstract}
The complexity of the challenges posed by teaching staff who are not ready and do not understand multicultural education today has become a major obstacle, especially in the 4.0 era as it is today. In addition, materials and resources must be free from biases, such as social class, gender, ethnicity, religion, and urban bias. Thus, authors of sources, materials, need to use the perspective of multicultural education, democracy and human rights in Era 4.0 in terms of implementing Islamic education in Indonesia. The purpose of this study is to determine the urgency and reflection of multicultural education, democracy and human rights in Indonesia, where Islamic education today continues to experience its own complexities of challenges. The results of the study show that multicultural education can be implemented for teachers, leaders, school members and campus communities who have a multicultural attitude and have the ability to properly organize Islamic education in the era 4.0 which is full of challenges. This will also be a challenge, because schools in general cannot be separated from stereotypes and prejudices that stem from a sense of primordialism, ethnicity, religion and social class. There is the Islamic concept of Rahmatan Lil 'Alamin as a solution, and also a method of paying attention to the situation in the delivery of subject matter without disturbing the students' souls.
\end{abstract}

Keywords: Reflection on Islamic Education, Multicultural, Democracy, Human Rights 


\section{ABSTRAK}

Kompleksitas tantangan yang ditimbulkan oleh tenaga pengajar yang tidak siap dan tidak memahami pendidikan multikultural dewasa ini telah menjadi kendala utama, khususnya di era 4.0 seperti sekarang ini. Selain itu, materi dan sumber daya harus bebas dari bias, seperti kelas sosial, gender, etnis, agama, dan bias perkotaan. Dengan demikian, penulis sumber, materi, perlu menggunakan perspektif pendidikan multikultural, demokrasi dan hak asasi manusia di Era 4.0 dalam hal implementasi pendidikan Islam di Indonesia. Tujuan penelitian ini adalah untuk mengetahui urgensi dan refleksi pendidikan multikultural, demokrasi dan hak asasi manusia di Indonesia, dimana pendidikan Islam dewasa ini terus mengalami kompleksitas tantangan tersendiri. Hasil penelitian menunjukkan bahwa pendidikan multikultural dapat dilaksanakan bagi guru, pemimpin, warga sekolah dan masyarakat kampus yang memiliki sikap multikultural dan memiliki kemampuan untuk menyelenggarakan pendidikan Islam secara tepat di era 4.0 yang penuh tantangan. Ini juga akan menjadi tantangan, karena sekolah pada umumnya tidak bisa lepas dari stereotip dan prasangka yang bersumber dari rasa primordialisme, suku, agama dan kelas sosial. Ada konsep Islam Rahmatan Lil 'Alamin sebagai solusi, dan juga metode memperhatikan situasi dalam penyampaian materi pelajaran tanpa mengganggu jiwa siswa.

Kata Kunci: Refleksi Pendidikan Islam, Multikultural, Demokrasi, Hak Asasi Manusia

\section{INTRODUCTION}

Indonesia is a country that is growing "towards democracy", where democracy was originally a political aspiration pursued through a peoplecentred process, meaning that people's aspirations are a source of inspiration and at the same time a determinant of the direction of the public decision-making process. So that the community and all walks of life, ethnicity, religion, and so on feel they have to be involved and accommodate their opinions and interests. Indonesia is one of the largest multicultural countries in the world. The truth of this statement can be seen from the socio-cultural and geographical conditions that are so diverse and wide. There are about 300 tribes who use almost 200 different languages (Yaqin, 2005, p. 4). The same thing as expressed by (Karim \& Munir, 2017) that If this is not the case then maybe your account needs to be specified. It is possible that the content may be conflicting and centralized, but this may not be the case with the content. It is estimated that in the mid-1980s, about $82.2 \%$ of the population consisted of 14 major ethnic groups with more than one million members. There are about $99.4 \%$ of the population are adherents of the five major religions in the world. Islam is approximately $86.9 \%$, Protestant $6.5 \%$, Catholic 3.15\%, Hindu 1\%, and Buddhist $0.6 \%$ (Sunarto, 2004).

More specifically, when viewed from the perspective, actions, and insights of each individual who exists on various kinds of social, cultural, economic, political phenomena and on other matters, it is undeniable that they have diverse views. For example, Indonesian people with various 
different backgrounds such as education, ethnicity, religion, social and economic class, have different actions and views on various actions and different views on various kinds of social phenomena such as democracy, human rights, gender, and other things. Likewise, Multicultural-Based Islamic Religious Education Learning (PAI), where multicultural education is an educational system that seeks to reduce social inequality, social class, social jealousy by introducing and socializing one of its orientations, namely togetherness (Heriadi, 2020). There are community members who do not support the democratization process in this country, but on the other hand not a few who want democratization. There are members who really care and always fight for human rights, but on the other hand, there are not a few people who don't care about these problems. Even deliberately crushing the human rights of others. There are community members who respond favorably and even support gender equality, but on the other hand not a few people are against it (Yaqin, 2005).

Talking about democracy, which today democracy is related to the form of government in a country and the way of life of a nation. Democracy provides space for the community to be involved in a participatory manner, uphold tolerance, guarantee open-mindedness, and diversity of ideas. The active role of the community is an indicator that the democratic process can run. Implementation of democracy in society means acknowledging the same human dignity and respect the diversity of cultures, races, languages, ethnicities, and religions that exist. Diversity and difference are features of a multicultural society. A society that upholds human rights while still paying attention to applicable norms (Sugiyar, 2017).

Nowadays, primordialism often occurs, namely self-righteousness, it will be increasingly difficult to carry out the formation of a process of harmonization of multicultural society (Prayit et al., 2017). So it is necessary to have multicultural education to prevent it. As with Satrio piningit, which is a term in Javanese tribes, "sacred savior of the archipelago" for prosperity to enter primordial Java in a political context (Yuliawati, 2019). Primordialism is the most important element in pluralism in Indonesia, this means the diversity of the Indonesian nation and plays a role in cultivating patriotism is a demand, but it becomes a challenge when build national culture (Nurjaman, 2021). As we all know that Islamic education is a forum to provide inclusive religious understanding to the community which is ultimately expected to contribute to the formation of a multicultural society with a harmonious life. Islamic education that is carried out properly will not clash with the community even in differences because differences are not something that is contested but a solution is sought to understand each other. Religion is no longer only for the good of the individual but religion must be able to manifest grace for the whole world (Muttaqin, 2018). Learning is an effort made by educators or teachers intentionally with the aim of conveying knowledge, by organizing and creating a learning environment system with various methods so that students can carry out learning activities more optimally. Although the term used is "learning". It does not mean that the teacher must eliminate his role as a teacher. In the 
context of learning, it does not mean at all increasing the role of students on the one hand and reducing the role of teachers on the other (Kirom, 2017).

If we look at the Fiqhiyah Rules with multicultural insights, historically, fiqh law was born and cannot be separated from the debate on the role of culture and texts since the time of the Companions, namely between Umar ibn al-Khattab and the other companions of the Prophet in the issue of converts to Islam and the distribution of spoils of war. Umar was based on the interests of the welfare and culture of the local community, while the other companions adhered to the sound of the texts of the Qur'an and Sunnah which had confirmed the legal rules for converts to Islam and the distribution of the spoils of war to those who were entitled. The debate between the role of culture and texts continues among fiqh scholars to this day (Mohtarom, 2017). Thus, we must be able to make Multiculturalism an ideology or school that discusses cultural pluralism, then strive to develop all human potential that respects plurality and heterogeneity as a consequence of cultural, ethnic, ethnic, and religious diversity. Seeing the reality of this plurality, multiculturalism tries to initiate a discourse on religious education, namely Islamic education, with the mission of religious pluralism, humanism and democracy. The hope is that with the discourse and mission, it can provide solutions and enlightenment towards a significant change in Islamic education with all its aspects, so that Islamic education becomes an inclusive and dynamic education that can bring education in Indonesia to be even better (Umar, 2012). Research conducted by Masnur Alam, and Daflizar Islamic Education with Multicultural Insights can be done by familiarizing and applying it in lecture activities where this multicultural-minded education is able to become a massive pioneer in creating peace and harmony in society (Alam \& Daflizar, 2018). With the existence of multicultural education at the high school level, it can also be applied where students are able to develop leadership skills, social skills, and other personal abilities with the hope that students are able to internalize the values of togetherness in a tangible form and suppress the values of differences between them so that with this is expected to have a positive impact on the process of interaction between them at any time and every time (Iman, 2017).

The form of multiculturalism is exemplified by (Ibrahim, 2015) in his journal which is a development of all human potentials that respects plurality and heterogeneity as a consequence of cultural, ethnic, ethnic, and religious diversity. Diversity is a very prestigious thing, on the other hand it can be a potential that encourages conflict and division, therefore today it is necessary for the Indonesian nation to have its own characteristics, especially education experts to promote multicultural attitudes, where the attitude here is commendable behavior which is a reflection of Islamic education itself (Sapirin, 2020). Kasinyo Harto also expressed the same thing that the paradigm of religious learning that has been adopted so far needs to be changed so as not to make people into intolerant, exclusive, selfish, narrow-minded, and oriented towards individual piety. so that the nuances of multicultural life can really be created in the learning process also need to be put forward (Harto, 2014). The achievement of a shared 
ideological consensus as an Indonesian nation, namely Pancasila. Pancasila which creates a harmonious relationship between primordial identity and national identity. This is the general will of all elements of the nation's children. The ideology of Pancasila must be defended because it was born from the sacred consensus of the nation's founding fathers and mothers, confirmed by the blood sacrifice of the founding fathers and mothers, as well as through the legitimacy of trials of state institutions attended by representatives of religion, ethnicity, islands, ethnic groups. nation, group and so on in Indonesia (Lura, 2017).

In the study of multicultural education as research by G.A. Putu Sukma Trisna in his journal stated that there are several main obstacles for teachers in developing multicultural education, namely their lack of knowledge and skills about multicultural education models and the limited learning media that can be used to facilitate students' personal and sociocultural experiences in community life, which include social conceptions, cultural conceptions, and personal conceptions in Indonesian language learning (Trisna, 2017).

In terms of the urgency of a multicultural education model that can be used as an effort in improving student's appreciation of local cultural wisdom, (Cahyono \& Iswati, 2017) also mentioned in the journal by Cahyono and Iswati that Today, where Indonesia is a pluralistic country, besides being able to become a wealth and pride and uniqueness of its own, of course it also becomes a crucial challenge, where the era of disruption as it is today also has its own challenges for the world of education, especially in Indonesia. Multicultural education which is an activity in developing various human potentials who are able to appreciate various kinds of differences and as an effort to increase students' appreciation of the existing local cultural wisdom needs to be redeveloped to increase the wisdom of the existence of superior education, especially in Indonesia.

Implementation of islamic education and multicultural education on students also needs to be developed as a means of human rights, where humans today are very intelligent in responding to the world's ark as it is today which is increasingly fragile and old. The implementation of this education by (Permana \& Ahyani, 2020) can be done through various methods or delivery methods, including instill a mutual attitude respectful, sincere, and tolerant of the diversity of cultures that live in the midst plural society. The same thing as research by (Abduloh \& Ahyani, 2020) that education through the heart can also be categorized as multifunctional education. Where the concept of heart education according to Imam Al Ghazali in his spectacular book, Ihya Ulumuddin, includes: (1) Healing a sick heart and reviving a dead heart: Always do dhikr, read the Qur'an, establish night prayers, build zuhud life, multiply remember dead. (2) Maintaining a healthy heart includes maintenance activities that can be carried out through the process of heart awareness through dhikr, while the routine dhikr process is expected to further strengthen intelligence and gentleness of heart. The process that is no less important is to prevent liver disease. Meanwhile, Al Ghazali's thoughts on the concept of heart education remain relevant to this day, this is evidenced by the existence of Laws and 
Government Regulations which still include efforts to educate the hearts of the Indonesian nation in this modern era. Like Imam Al Ghazali in educating the heart in accordance with today's children's era and is not absolute. From this, the education of the heart is dynamic and it can be implied that the values of the concept of heart education are in contemporary times and it is still relevant.

Likewise (Napsiah, 2012) opinion that the debriefing material provided by the campus which in this case is from the Study Program (Prodi) in a university to students participating in PKL (Field Experience Practice), which contains the values of pluralism makes a great contribution to students, so that these values are internalized and expressed in the form of harmonious cooperation with community groups. Thus, street vendors are one of the strategies to create education that is sensitive to reality so that tolerance for pluralism is formed in society. Exemplified in the tolerance education launched by islam and local culture in timor, that prioritizing an attitude of religiosity is the main thing, which is that religious teachings come from God's revelation while culture is a human creation. However, religion and culture are two things that influence each other. Religious values and cultural values penetrate and shape the character of the people who adhere to them. so that later Islamic life in East Nusa Tenggara Province in its interaction with local culture can boast of what is called religious tolerance. Muslims in Timor who come from various ethnic and cultural backgrounds are people who adhere to their religious beliefs. But on the other hand, they also adhere to and adhere to their culture. In its embodiment, religion purifies culture and culture shapes the character of the community to be loyal to their religious beliefs (Bolong, 2020).

Thus, this paper, which is related to the Urgency and Reflection of Multicultural Islamic Education, Democracy and Human Rights in Indonesia, is a unique and interesting matter to be studied and developed in order to maintain the integrity of the values of human rights, especially the right to be a good citizen. . so that the researcher intends to study and explore and uncover how the relevance of Islamic Education Reflection which incidentally puts forward the concept of Multicultural, Democracy and Human Rights, especially in Indonesia, is maintained its authenticity.

Based on the problems above, regarding the importance of multicultural education in which the urgency of this educational model needs reflection that is applied in the world of Islamic education, especially in Indonesia, namely Multicultural education and also Democracy and Human Rights (HAM) in Indonesia, so it is necessary to find a strategy specifically in solving these problems through all fields: including social aspects, political aspects, cultural aspects, economic aspects, and also educational aspects. In this regard, multicultural education offers an alternative through the application of educational strategies and concepts based on the use of pluralism in society, especially for students as well as socialization between ethnic diversity, culture, language, religion, social status, gender, ability, age and also on the aspect of race, all of which is a manifestation of the multiculturalism that characterizes the Indonesian nation. The most important approach in the 4.0 era as it is today, where the 
era of disruption has run rampant so that with the application through multicultural education, a unique and interesting strategy will emerge to be applied in the world of education, where education in Indonesia itself is not only aimed at making students easy to understand. the lessons he learns, but also to increase the awareness of students (students) at school to always behave humanist, pluralist, and democratic. Therefore, researchers in this case are trying to uncover and explore the Urgency and Reflection of Multicultural Islamic Education, Democracy and Human Rights (HAM) in Indonesia, its implementation in the 4.0 era; with several problem formulations including 1) what are the implications of Understanding Democracy in Indonesia for Islamic Education today?; 2) how is the understanding of human rights in Indonesia and its implications for Islamic education in Indonesia?; 3) What is the Strategy for Development of Multicultural Islamic Education in Indonesia in Era 4.0?.

\section{RESEARCH METHOD}

The method in this study is Library Research where the data sources are obtained from various literary sources in the form of books, journals, the internet and other sources related to multicultural education, democracy and human rights in Era 4.0 in terms of implementing Islamic education in Indonesia. Indonesia, so that later this research can uncover and explore the urgency and reflection of multicultural education, democracy and human rights in Indonesia, where Islamic education today continues to experience the complexity of its own challenges. In addition, later discussions related to multicultural education, democracy and human rights in Era 4.0 can be implemented as the concept of Islamic education which Rahmatan Lil 'Alamin is a solution, and also a method of paying attention to the situation in the delivery of subject matter without disturbing students' psychology in learning.

\section{DISCUSSION}

\section{A. Multicultural Islamic Education in Indonesia}

Multicultural education can be defined as "education for or about cultural diversity in response to demographic and cultural changes in a particular community or even the world as a whole". This is in line with the opinion that education should not only be seen as an "ivory tower" that tries to stay away from social and cultural realities. Education must be able to create an educated and educated society, not a society that only glorifies social prestige as a result of the wealth and prosperity it experiences or the offspring it inherits. The term "multicultural education" can be used on both a descriptive and normative level, describing educational issues and problems related to multicultural societies. Furthermore it also includes the notion of on considerations of educational policies and strategies in a multicultural society. In this descriptive context, the multicultural education curriculum must cover subjects such as: tolerance; themes of ethno-cultural and religious differences; the dangers of discrimination: conflict resolution and mediation; Human rights: democracy and plurality; universal humanity and other relevant subjects (Tilaar, 2002). 
Multicultural education is a progressive approach to transforming education that thoroughly uncovers deficiencies, failures and discriminatory practices in the educational process (El-Ma'hady, 2004). In line with that, (Asy'arie, 2004) argues that multicultural education is a process of inculcating a respectful, sincere and tolerant way of life towards cultural diversity that lives in the midst of a plural society. With multicultural education, it is hoped that there will be resilience and mental flexibility of the nation in facing social conflicts. (Yaqin, 2005) suggests that multicultural education is an educational strategy that is applied to all types of subjects by using the cultural differences that exist in students such as differences in ethnicity, religion, language, gender, social class, race, ability and age so that the learning process becomes effective and easy. At the same time, multicultural education will also train and build the character of students to be able to be democratic, humanist, and pluralistic in their environment. This means that students are not only expected to be able to easily understand, master and have good competence in the subjects taught by the teacher, students are also expected to be able to always behave and apply democratic values, humanism and pluralism at school or outside of school.

Multicultural education is a response to the development of diversity in the school population, as well as demands for equal rights for each group. In another dimension, multicultural education is curriculum development in educational activities to enter various views, histories, achievements and concerns for people from other ethnicities. This means broadly that multicultural education includes all students without distinguishing groups such as ethnicity, race, culture, social strata, religion and gender, so as to be able to lead students to become human beings who are tolerant and appreciate differences. In addition to ethnic differences, actually differences in beliefs (religions) are also quite prone to potential conflicts that can destroy togetherness, brotherhood, and infrastructure. In Indonesia, such a case occurred in the Poso region which turned out to be quite difficult to resolve. Countless how many tears; life; property and family integrity that was sacrificed for the purpose of the struggle is not clear. The deep hatred between ethnic groups who happen to have different religions has removed the sense of togetherness and regional solidarity.

Each of these religious groups thinks that they are in the right position; Religious harmony that is learned through textbooks at school seems meaningless at all. It seems that conflicts caused by religious differences are quite difficult to handle, because the ideological primordial factors that have been embedded in a person's soul are difficult to remove. Because it has become ingrained and become part of the life and behavior of the individual. For an individual to be able to have an attitude of tolerance and respect for religious differences, then these values should be instilled from childhood through various opportunities, both in the form of discourse and concrete actions. In this case the exemplary attitude of parents, teachers and adults around the individual has a very big influence. Religion should be a driving force for mankind to establish peace and improve welfare for all mankind on this earth. Unfortunately, in real life, religion is 
actually one of the causes of violence and the destruction of mankind, concrete examples in Bosnia Herzegovina, in Ireland and so on. In Indonesia, there were also a series of bitter incidents such as in Poso, Ambon (1999-2002); Surabaya Situbondo and Tasikmalaya (1996), and so on. Not only the casualties were very large, but also hundreds of places of worship (both churches and mosques) were burned and destroyed.

After such a harsh reality, it is very necessary to develop preventive measures so that the problem of religious conflict will not be repeated in the future. Providing education about pluralism and religious tolerance through schools are some of the preventive measures that can be applied. In this regard, it is important for educational institutions in a multicultural society to teach peace and conflict resolution as contained in the values of multicultural education. In multicultural education, a teacher or lecturer is not only required to be able to professionally teach the subjects he teaches. However, it is also able to instill the values of inclusive diversity in students. In the end, with these steps, the expected output from a teaching and learning process will be school or university graduates who are not only smart in accordance with the disciplines they practice, but are also able to apply the values of diversity in understanding and appreciating the existence of adherents. other religions and beliefs.

\section{B. Understanding of Democracy in Indonesia Implications for Islamic Education}

Bonger (in Badruli, 2005) as quoted by Farida Hanum in her journal, it is explained that explains that modern democracy is theoretical, namely in a formal sense and democracy in a material sense (Hanum, 2006). Formal democracy only contains an acknowledgment that the determining factor in the state is the will of the people, which then becomes a large part of the people. Equality in the political field that is not accompanied by efforts to reduce differences in the economic field leads to exploitation in the material field, which results in democracy in the political field not working properly. Formal democracy is also known as liberal democracy. The essence of democracy lies in the guarantee that it is given the rights that are fundamental to the recognition of the independence of every person who becomes a citizen. So the emphasis is on efforts to eliminate differences in the economic field, while equality in the political field is not given much attention. As a result, material democracy will lead to coercion in the spiritual field. This democracy is also called Eastern democracy, which is commonly adopted in socialist countries.

For Indonesia, which is developing itself as a democratic country, the role of education is increasingly important, because to grow and develop a civic culture requires systematic and integralistic efforts so that the younger generation can grow and develop in the world of education. Cultivating and developing a civic culture is a fairly fundamental capital for efforts to realize and enforce democracy in society. Democratic values are actually values needed to develop democratic governance. Based on these values or conditions, democratic governance is developed. These values include freedom (groups, opinions, participation), respect for other people/groups, 
equality, cooperation, competition, trust. In addition to the values mentioned above, a number of conditions are needed so that these values can be upheld as the foundation of democracy. Equality or egalitarianism is one of the fundamental values needed for the development of democracy in Indonesia. Equality is defined as equal opportunity for every citizen. Equality gives place to every citizen regardless of ethnicity, language, region, or religion. This value is needed for a heterogeneous society such as Indonesia, which is very multi-ethnic, multi-lingual, multi-regional and multi-religious.

Gabriel Almond (1996), As quoted by Farida Hanum in her journal, it is explained that, in a study to test the hypothesis that there is a link between the success of a nation's democratization and the existence of a democratic socio-political culture and structure, concludes the following: 1). Democratic culture is a mixed culture, namely between freedom/participation on the one hand and norms of behavior on the other. 2). The culture of democracy is rooted in the culture of society in general, which contains high social trust and civicness, the tendency of horizontal/equal working relationships. 3). The culture of democracy always requires and is based on civil society. 4). The democratic culture held by the people in a country is very dependent on the behavior of the government in democracy (Chamim et al., 2003). In developing a democratic culture, Almond said that a nation must go through three stages, the first stage is the stage of developing democratic institutions. This stage creates social conditions and individual personalities that support the realization of democracy. The second stage is a process to realize individual attitudes that support democracy. At the beginning of the reformation, it seems that most of the citizens of the nation were pro-democratic. The third stage is an effort to realize a democratic social structure and political culture. These stages can be started through educational institutions, especially through multicultural education.

The main goal of multicultural education is to change the approach to teaching and learning towards providing equal opportunities for every child. So nothing is sacrificed for the sake of unity. For this the groups must be peaceful, understand each other, end the conflict but still emphasize the common goal of achieving unity. In students or students are instilled lateral thinking, diversity and uniqueness are appreciated. That means there must be a change in attitudes, behavior and values, especially for the academic community at school. When students or students are among each other with different backgrounds they must learn from each other, interact and communicate, so that they can accept the differences between them as something that enriches them. Gibson As quoted by (Hernandez, 1989) in his writings, it is explained that, states that multicultural education is a process in which individuals develop ways of perceiving, evaluating behavior in cultural systems that are different from their own cultural systems. Gibson's view implies that education is not just a school matter or multicultural education with just a formal school program. This view is broader, education as a transmission of culture both through formal and informal learning. In addition, this view no longer equates cultural groups 
with ethnic (ethnic) groups. This means that it is no longer associated with culture only with ethnic groups (tribes), but is broader than that because community groups that do not consist of one ethnicity (tribe) also have a distinctive culture as a result of the interaction between members of their community. Therefore, it is very important for students or students to have the ability to be able to live in diversity.

Implementing multicultural education in schools does not have to be a special subject and enter the formal curriculum (change the existing curriculum). The most important thing can be implemented directly in real action. In line with that, Sri Sultan Hamengkubuwono X (2004) also revealed that in multicultural education, teachers or lecturers must set an example of attitudes and examples such as those in multi-cultural values, so that students and students will follow them. Furthermore, he added that if you want to be a good teacher and lecturer, you must be able to be an example who respects differences, is tolerant, loves peace and respects each other for his students.

\section{Understanding of Human Rights in Indonesia Implications for Islamic Education}

The problem is, when human rights are exercised without heeding the obligations of living in society and the state, then if human rights are expressed without limits, it will give birth to anarchy. Yet as we know, if everyone has human rights, then automatically one's human rights are always within the relative limits of other people's rights. Therefore, the application and expression of human rights must always take into account the human rights of others. In other words, the limit of one person's space for expression of human rights is the relative space for the expression of another's rights. The meeting point between one's human rights and the rights of others is our obligation. Liability to what? Obligations to values, norms and laws and regulations. Therefore, the law (written or unwritten) is the boundary where human rights may and may not be expressed. Without law, human rights will only be the basis for chaos. The law (written or unwritten) is the controlling node for the implementation of human rights.

Tracing human history, we can observe the ongoing tug-of-war between good and evil, justice and injustice, upholding human rights and human rights violations. The process of human rights violations has occurred since time immemorial, as well as enforcement efforts. Because human rights violations have existed and have continued throughout human history, efforts to enforce them continue to be made more perfect. However, because changes (economic, political, socio-cultural, technological, etc.) continue to occur, what is normative often has to be continuously updated. What used to be considered perfect, turns out in a different era it cannot reach new types of human rights violations. This has happened since the time of the Magna Charta Libertum (1215) which essentially forbade the arbitrary detention, confiscation and destruction of property by the king; Hebeas Corpus (1670), which prohibits arbitrary arrests; Bill of Rights (1680) which required the king to recognize parliamentary rights over government; Declaration des Droit Des Hommes et Des Citoyens (1789) 
which regulates the right to life, property rights, security rights, rights not to be oppressed, rights of citizens to participate in making laws; to the General Declaration of Human Rights (1948). Subsequently, various international covenants were made and implemented in various state parties. This milestone in the history of human rights basically describes the struggle to continue to perfect efforts to respect, promote, and fulfill human rights, dealing with the development of various human rights violations that occur in society.

\section{Strategy for the Development of Multicultural Islamic Education in Indonesia in Era 4.0}

According to Hernandez (in Conny S., 2004) there are at least 4 (four) approaches that can be taken to implement multicultural education, namely: 1) contribution approach; 2) additional approaches; 3) transformation approach; and 4) social action approach. The first and second approaches in general the basic structure and objectives remain unchanged. The structure is the same as the national curriculum and the microculture content provided is limited to events, commemorations, and heroes. This approach is only a supplement designed for all students or students, but they do not get a general view of the role and framework of ethnic and microcultural groups thinking. Generally, they only introduce ethnic symbols (such as clothes, weapons, house shapes, etc.). The content is added to the core curriculum without changing its basic assumptions and structure. The third approach, namely transformation, changes basic assumptions and allows students or students to view concepts, issues, themes and problems from a microcultural perspective. The fourth approach is the transformation approach by adding components that require students or students to make decisions about these social problems, and take action in everyday life.

From the explanation above regarding the Urgency and Reflection of Multicultural Islamic Education, Democracy, and Human Rights in Indonesia, there are various types of education The challenge faced is that in the process of socializing and providing multicultural education policies in the national curriculum, it is necessary to involve all relevant stakeholders at the macro and micro levels in the education system as a whole. This is because the challenges faced are also related to lack of understanding, large variations in interpretation of meaning and rejection due to the interests of several stakeholders, especially in the current era of autonomy. namely from Human Resources (Educators) who are not ready and the lack of understanding of the concept of multiculturalism which has become the main obstacle. In addition, materials and resources must be free from biases, such as social class, gender, ethnicity, religion, and urban bias. Thus, the authors of sources, materials, need to use a multicultural perspective. Multicultural education can be implemented if teachers, leaders, schools and campus communities have a multicultural attitude and have the ability to implement it well. This will also be a challenge, because schools in general cannot be separated from stereotypes and prejudices that 
come from a sense of primordialism, ethnicity, religion and social class, Reflection on multicultural Islamic education today where the all-digital era can be done by promoting the concept of Islam Rahmatan Lil'Alamin where the attitude of tolerance between differences needs to be put forward, especially in the world of education, and not only that the concept of Rahmatan lil 'alamin can also be applied in the world of politics, law, economics, and so on depending on how the level of need is being lived. This is as research proclaimed by (Ahyani et al., 2021) that tolerance with the concept of Rahmatan Lil 'Alamin is not limited to mu'amalah, but also in the field of education, where the method needed in learning is a method/trick in conveying material to participants. taught by teachers (Educators) without disturbing the psyche of students (Ahyani, 2021). Other things can also be done by preventing the entry of fake news in the world of education which is considered to divide the country, meaning that the world of education by not accepting fake news from various online media will make a country stable (Rijal et al., 2021).

So far, the nuances of multicultural education have been given in schools through the first and second approaches. In some past and present subject matter it has shown importance to the diversity of society. For example, the materials contain calls for tolerance between religions. However, information about cultural diversity is limited to knowledge of names, places, events, such as royal names, heroes against the Dutch, traditional clothing and dances. This is a form of multicultural education referred to by Derman Sparks (in Kamanto, 2004) as "Tourist Multiculturalism" and by Banks (2002) as "The Contribution Approach." According to Kamanto (2004:53) in the 2004 KBK curriculum, there are already subjects that contain multicultural education such as sociology education. The outline of sociology subject matter for high school students states that the function of sociology education is to improve the ability to think, behave, and interact in various social and cultural realities on the basis of ethics, values and norms, and its practical objectives include developing behavioral skills, critical attitudes., and rational students in dealing with various kinds of social situations, culture, society and social problems faced in everyday life. One of the expected social skills is "assessing socio-cultural diversity in social life". In the lesson outline for the first semester of the second grade of high school the word "multicultural" is explicitly stated; students are expected to conduct research on the formation of multicultural societies, present research findings on the formation of multicultural societies, and demonstrate the attitudes and behaviors expected of members of multicultural societies.

What is contained in the high school sociology education curriculum above, although only in certain parts of the overall curriculum, but the existing multicultural education has implemented the third and fourth level approaches as described in the beginning, namely at the level of the transformation approach and social action approach. Even if multicultural education is not included in the core curriculum as a separate subject, multicultural materials can be included in certain parts of the subject matter in the field of study in schools, it has greatly helped students and 
students in getting and understanding multicultural education. . In addition, so that education is more multicultural, the curriculum, learning models, school atmosphere, extracurricular activities, and the role of teachers must be made multicultural. The content, approach, and evaluation of the curriculum must respect differences and not be discriminatory. Content and teaching materials in schools need to be chosen that really emphasizes the recognition and appreciation of other cultures and values. For example, in all subject areas, values and figures from other cultures are included so that students understand that in each culture, knowledge is developed. Examples of scientists and technological results, need to be drawn from various cultures and backgrounds including gender. The similarities and differences between cultures need to be explained and understood. Students are helped to better understand the values of other cultures, accept, and appreciate them. For example, in teaching food, clothing, ways of life, it is explained not only from their own culture, but also from others.

The learning model in the classroom also needs to be multicultural, by using a variety of different approaches. Presentation of materials, including mathematics, in giving examples, teachers need to choose a variety of values. Books written in lessons also need to be structured to respect other cultures and respect gender. In the past many books contained examples of certain cultural stereotypes, now they must be more comprehensive, including so as not to be gender biased. In the New Order, often because they were afraid of SARA, many textbooks did not dare to contain symbols or pictures from other religions. the reason is that there is no tension. In my opinion, in this democratic era, and to help students recognize and appreciate it, we should not be afraid to include examples from other beliefs and religions. By being covered, the child does not understand the other, so it will be more difficult to appreciate the difference. The school atmosphere is very important in the cultivation of multicultural values. Schools must be built in an atmosphere that supports respect for other cultures. Relations between teachers, employees, students of different cultures are well regulated, there is mutual respect. Children from other groups are not rejected but rewarded. Even more important, especially at the elementary-high school level, school decorations need to be arranged with multicultural nuances. Even though the school is on the island of Java, the decorations and room decorations are made of various ethnic cultures in Indonesia, for example, so that they understand other values.

Extracurricular activities should also be multi-valued. Respect for people who are different from other cultures will be more developed when students practice and experience it themselves. Thus, the live-in model, living in the midst of people from other cultures, can greatly help students appreciate "other cultures". For example, students from Bali participated in a one-week live-in among the Sundanese. If they experience that it is well received, they will be helped to appreciate Sundanese culture more. Projects and committees in good schools are also organized with more variety and variety. Each committee consists of students from various ethnic groups, races, religions, cultures, and genders. This will further foster the spirit of 
unity in existing differences. Discussions and debates about conflict issues in society caused by cultural differences can help students better understand the meaning of difference. So, it is important that students are not isolated from social problems. They are invited to critically observe what is happening in society, especially in terms of respecting the values of others. Students are given the opportunity to explore the problems of multicultural society. Various ideas are tried to be accepted and opened, so that children are aware of the diversity.

Learn other tribal languages, very useful. Indonesia consists of many islands and tribes with different languages. Our country has one national language, Indonesia. And, this is good for communication tools between Indonesian citizens. However, what should not be left out is that we will be more helpful in respecting other people, if we can understand their language. Through the language, especially being able to use it, people will easily understand the deepest meanings of other people's cultures. So, the more we know the languages of other tribes, the more we will encourage us to understand them more deeply and to accept and appreciate them. Presumably efforts to respect other cultures can also educatively emphasize the importance of learning the language of other tribes. If this encouragement is emphasized to students from the start, it will help them understand people from other ethnic groups better.

\section{CONCLUSION}

From the explanation above regarding the Urgency and Reflection of Multicultural Islamic Education, Democracy, and Human Rights in Indonesia, there are various types of education The challenge faced is that in the process of socializing and providing multicultural education policies in the national curriculum, it is necessary to involve all relevant stakeholders at the macro and micro levels in the education system as a whole. This is because the challenges faced are also related to lack of understanding, large variations in interpretation of meaning and rejection due to the interests of several stakeholders, especially in the current era of autonomy. namely from Human Resources (Educators) who are not ready and the lack of understanding of the concept of multiculturalism which has become the main obstacle. In addition, materials and resources must be free from biases, such as social class, gender, ethnicity, religion, and urban bias. Thus, the authors of sources, materials, need to use a multicultural perspective. Multicultural education can be implemented if teachers, leaders, schools and campus communities have a multicultural attitude and have the ability to implement it well. This will also be a challenge, because schools in general cannot be separated from stereotypes and prejudices that come from a sense of primordialism, ethnicity, religion and social class, Reflection on multicultural Islamic education today where the all-digital era can be done by promoting the concept of Islam Rahmatan Lil'Alamin where the attitude of tolerance between differences needs to be put forward, especially in the world of education, and not only that the concept of Rahmatan lil 'alamin can also be applied in the world of politics, law, economics, and so on depending on how the level of need is being lived. 


\section{REFERENCES}

Abduloh, A. Y., \& Ahyani, H. (2020). Pendidikan Hati Menurut A1Ghazali (Keajaiban Hati: Penjelasan Tentang Perbedaan Antara Dua Maqom). Jurnal Tawadhu, 4(2), 1209-1227.

Ahyani, H. (2021). Situation Method In Learning Arabic In The Era Of Industrial Revolution 4.0. Al-Fashahah: Journal of Arabic Education, Linguistics, and Literature, 1(1), 1-15.

Ahyani, H., Slamet, M., \& Tobroni. (2021). Building the Values of Rahmatan Lil 'Alamin for Indonesian Economic Development at 4.0 Era from the Perspective of Philosophy and Islamic Economic Law. AL-IHKAM: Jurnal Hukum \& Pranata Sosial, 16(1), 121-151. https://doi.org/10.19105/al-lhkam.v16i1.4550

Alam, M., \& Daflizar, D. (2018). Pendidikan Islam Berwawasan Multikultural. Belajea: Jurnal Pendidikan Islam, 3(2), 103-124. https://doi.org/10.29240/belajea.v3i2.560

Asy'arie, M. (2004). Pendidikan Multikultural dan Konflik Bangsa. Majalah Kompas, 1-6, 5.

Bolong, B. (2020). Islam And Local Culture In Timor. Indonesian Journal of Interdisciplinary Islamic Studies, 4(1), 57-83. https://doi.org/10.20885/ijiis.vol4.iss1.art4

Cahyono, H., \& Iswati, I. (2017). Urgensi Pendidikan Multikultural Sebagai Upaya Meningkatkan Apresiasi Siswa Terhadap Kearifan Budaya Lokal. Elementary: Jurnal Ilmiah Pendidikan Dasar, 3(1), 15-29.

Chamim, A. I., Cipto, B., Nashir, H., \& Muhammad, A. (2003). Pendidikan Kewarganegaraan (civic education): Menuju kehidupan yan demokratis dan berkeadaban. Yogyakarta: LP3 UMY.

El-Ma'hady, M. (2004). Multikulturalisme dan Pendidikan Multikultural (Sebuah Kajian Awal).

Hanum, F. (2006). Pentingnya implementasi pendidikan multikultural di sekolah. Cakrawala Pendidikan, 1(3), Article 3. https://doi.org/10.21831/cp.v1i3.8598

Harto, K. (2014). Model Pengembangan Pendidikan Agama Islam Berbasis Multikultural. Al-Tahrir: Jurnal Pemikiran Islam, 14(2), 407-426. https://doi.org/10.21154/al-tahrir.v14i2.122

Heriadi, H. (2020). Pembelajaran Pendidikan Agama Islam (PAI) Berbasis Multikultural. Al-Wardah: Jurnal Kajian Perempuan, Gender Dan Agama, 14(1), 87-102. https://doi.org/10.46339/alwardah.v14i1.247

Hernandez, H. (1989). Multicultural Education: A teacher Guide to linking Context, Process, and Content. New Jersy \& Ohio : Prentice.

Ibrahim, R. (2015). Pendidikan Multikultural: Pengertian, Prinsip, dan Relevansinya dengan Tujuan Pendidikan Islam. ADDIN, 7(1), Article 1. https://doi.org/10.21043/addin.v7i1.573

Iman, M. (2017). Implementasi Pendidikan Islam Multikultural Di Madrasah Aliyah Negeri Dolok Masihul Serdang Bedagai. Journal Analytica Islamica, 6(1), 54-65. 
Karim, A., \& Munir, M. (2017). Pendidikan Agama Islam Berbasis Multikultural. Al-I'tibar: Jurnal Pendidikan Islam, 3(1), 1-16. https://doi.org/10.30599/jpia.v3i1.197

Kirom, A. (2017). Peran Guru Dan Peserta Didik Dalam Proses Pembelajaran Berbasis Multikultural. Jurnal Al-Murabbi, 3(1), 6980 .

Lura, H. (2017). Nasionalisme dan Primodialisme: Pergumulan Menjadi Indonesia di Tengah Pluralitas Bangsa. Kinaa: Jurnal Teologi, 2(2), Article 2. https://doi.org/10.0302/kinaa.v2i2.1044

Mohtarom, A. (2017). Kaidah Fiqhiyah Berwawasan Multikultural. Jurnal Al-Murabbi, 3(1), 121-134.

Muttaqin, M. R. (2018). Peran pendidikan agama Islam dalam membangun wawasan multikultural di SMK Negeri 4 Purworejo. Jurnal Pembangunan Pendidikan: Fondasi Dan Aplikasi, 6(2), 103111. https://doi.org/10.21831/jppfa.v6i2.22555

Napsiah, N. (2012). Revitalisasi Pendidikan Multikultural Di Perguruan Tinggi Islam. Jurnal Tapis: Jurnal Teropong Aspirasi Politik Islam, 8(2), 119-139. https://doi.org/10.24042/tps.v8i2.1568

Nurjaman, A. (2021). Tantangan primordialisme dalam upaya membangun budaya politik nasional. Satwika: Kajian Ilmu Budaya Dan Perubahan Sosial, 5(2), 370-383.

https://doi.org/10.22219/satwika.v5i2.17990

Permana, D., \& Ahyani, H. (2020). Implementasi Pendidikan Islam Dan Pendidikan Multikultural Pada Peserta Didik. Jurnal Tawadhu, 4(1), 995-1006.

Prayit, P., Pitoewas, B., \& Yanzi, H. (2017). Pengaruh Sikap Primordialisme Terhadap Upaya Pembentukan Proses Harmonisasi Masyarakat Multikultur. Jurnal Kultur Demokrasi, 5(3), $\quad$ Article 3. http://jurnal.fkip.unila.ac.id/index.php/JKD/article/view/12600

Rijal, M. B., Ahyani, H., \& Basit, A. (2021). The Dangers of Hoaxes in Building Civil Society in the Era of the Industrial Revolution 4.0. International Journal of Social Science and Religion (IJSSR), 13-34. https://doi.org/10.2020/ijssr.v2i2.42

Sapirin, S. (2020). Pendidikan Islam dan Multikulturalisme di Indonesia. Anthropos: Jurnal Antropologi Sosial dan Budaya (Journal of Social and Cultural Anthropology), 5(2), 108-122. https: / / doi.org/ 10.24114/antro.v5i2.14329

Sugiyar, S. (2017). Demokrasi Dan Hak Asasi Manusia Dalam Masyarakat Multikultural. Jurnal Al-Murabbi, 3(1), 51-68.

Sunarto, K. (2004). Multicultural Education in Indonesia and Southeast Asia Stepping into The Unfamiliar. Jurnal antropologi Indonesia.

Tilaar, H. A. R. (2002). Perubahan sosial dan pendidikan: Pengantar pedagogik transformasi untuk Indonesia (Jakarta) [Text]. Gramedia Widiasarana Indonesia.

http:/ / library.fip.uny.ac.id/opac/index.php?p=show_detail\&id=17 11 
Trisna, G. A. P. S. (2017). Pengembangan Pendidikan Multikultur Dalam Pembelajaran Bahasa Indonesia Di Sekolah Dasar. Jurnal Ilmiah Sekolah Dasar, 1(2), 107-112. https://doi.org/10.23887/jisd.v1i2.10145

Umar, A. K. (2012). Pendidikan Agama Berbasis Multikulturalisme (Studi Kritis). At-Ta'dib, 7(2), Article 2. https://doi.org/10.21111/at-tadib.v7i2.76

Yaqin, M. A. (2005). Pendidikan Multikultural: Cross-Cultural Understanding untuk Demokrasi dan Keadilan. Pilar Media.

Yuliawati, E. (2019). Satrio Piningit; Budaya Politik Diantara Primordialisme Dan Demokrasi. Bricolage: Jurnal Magister Ilmu Komunikasi, 1(02), Article 02. https://doi.org/10.30813/bricolage.v1i02.1630 